\title{
IMPROVING PRODUCTION AND CHARACTERS OF POTATO MICROTUBERS AND MINITUBERS
}

\author{
Nermeen A. E. Abd El Wadod, A. M. H. Abd El Aal and Nadia M. Ibrahim \\ Potato and Vegetatively Propagated Vegetables Dep., Hort. Res. Inst., A. R. C., Egypt.
}

Received: Jun. 15, 2017

Accepted: Jul. 10, 2017

\begin{abstract}
This investigation was carried out during the seasons 2012 and 2013 on potato cv. Diamant at the Tissue Culture Laboratory and the greenhouse of Potato and Vegetatively Propagated Vegetables Department, Horticulture Research Institute, Dokki, Giza, Egypt. The present study aimed to study the effect of the in vitro application of chitosan, calcium chloride and the concentration of ammonium nitrate and potassium nitrate on potato tuberization. In addition, to study the effect of foliar application of chitosan, chelated calcium and potassium silicate on growth and yield of the minituber ex vitro.

Results revolved that $500 \mathrm{mg} / \mathrm{l}$ chitosan gave the highest values of number of shoots and node/plantlets, number of microtuber, fresh and dry weight of shoots and microtubers fresh weight after 8 weeks from culture in vitro. Furthermore, ex vitro spraying with $500 \mathrm{mg} / \mathrm{l}$ chitosan or the mixture of $350 \mathrm{mg} / \mathrm{l}$ chelated calcium $+400 \mathrm{mg} / \mathrm{l}$ potassium silicate produced the highest values of plant length, leaves number/plant, fresh and dry weight of leaves on 75 days after planting. As well as, minituber characteristics (number of minituber /plant, minituber fresh and dry weight/plant, average minituber weight and weight of minituber /plant according to its size) after 100 days from planting recorded the highest significant values with foliar application of 500 $\mathrm{mg} / \mathrm{l}$ chitosan or the mixture of $350 \mathrm{mg} / \mathrm{l}$ chelated calcium $+400 \mathrm{mg} / \mathrm{l}$ potassium silicate.

It could be recommended that adding chitosan at $500 \mathrm{mg} / \mathrm{l}$ to in vitro microtuber production medium ( $M S+8 \mathrm{mg} / \mathrm{l} B A+80 \mathrm{~g} / \mathrm{l}$ sucrose) was preferable to produce microtubers. Also, the ex vitro spraying of $500 \mathrm{mg} / \mathrm{l}$ chitosan or the mixture of $350 \mathrm{mg} / \mathrm{l}$ chelated calcium plus $400 \mathrm{mg} / \mathrm{l}$ potassium silicate could be useful for minituber production and enhancing its yield characteristics.
\end{abstract}

Key words: Potato, Chitosan, nitrate potassium, Potassium Silicate, Chelated calcium, microtuber and minituber

\section{INTRODUCTION}

Potato is one of the main important vegetable crops in Egypt. It occupies the first rank in export among the different vegetable crops in 2016. The cultivated areas reached to 437386 fed. Its total productivity was 4955445 ton. Also, Egypt exported 632090 tons to the different markets especially England, West European and some Arab countries (Ministry of Agricultural, 2016).

Half a century has passed since in vitro tubers (microtubers) were first described in potato, but their adoption as a seed propagule has been uneven globally consensus in lacking regarding optimal production practices for microtubers and their relative productivity in relation to the propagules for minituber production (Donnelly et al., 2003). Although, many reports of the in vitro production of microtubers little is known about growth and yield from microtubers planted in the field (Kawakami et al., 2003).

Kowalski et al., (2006) added chitosan at $0.0001,0.001,0.01,0.1$ and $1 \mathrm{~g} / \mathrm{l}$ to potato micropropagation media. Chitosan at $1 \mathrm{~g} / \mathrm{l}$ showed improvement of microtuber quality, plant growth in vitro, helped in the acclimatization ex vitro and finally increased the yield of minituber. Moreover, Zakaria et al., (2009) investigated the effect of chitosan at $5,15,50,150,500,750$ and $1000 \mathrm{mg} / \mathrm{l}$ on potato plantlets and found that chitosan at 
$500 \mathrm{mg} / \mathrm{l}$ significantly increased shoots and root fresh weight, improved acclimatization of plantlets in green house and finally increased minituber yield.

Calcium plays an important role in tuberization in vitro. The reducing of calcium uptake resulted in the inhibition of tuberization (Balamani et al., 1986). On the other hand, Ozgen and Palta (2004) mentioned that the application of calcium decreased tuber number but increased tuber calcium content with no significant effect on tuber yield. Also, Arvin et al., (2005) found that the calcium concentration at $3 \mathrm{mM}$ was high enough for optimal tuberization and increased microtuber fresh weight of potato. Increasing calcium level in Murashige and Skoog medium from 3 to 5 or $15 \mathrm{mM}$ improved growth of in vitro potato plantlets and the $15 \mathrm{mM}$ concentration was the best (Habib et al., 2005).

Potato plantlets growth was less with either $\mathrm{NH}_{4}^{+}$or $\mathrm{NO}_{3}^{-}$as a sole nitrogen source (Avila et al., 1994). Both growth and morphogenesis in tissue culture are considerably influenced by the availability and form of nitrogen (George et al., 2008). Moreover Villamor (2010) indicated that nitrogen in the form of $\mathrm{KNO}_{3}$ significantly improved the proliferation rate of ginger in vitro. Leaf growth and root formation was better in media devoid of $\mathrm{NH}_{4} \mathrm{NO}_{3}$. In addition Motallebi-Azar et al., (2011) reported that potato plantlets on media supplemented with $2400 \mathrm{mg} / \mathrm{l}$ of $\mathrm{NH}_{4} \mathrm{NO}_{3}$ gave the highest number of lateral shoot than the 800 and $1900 \mathrm{mg} / \mathrm{l}$. Andreea et al., (2011) studied the effect of three levels of total nitrogen (30, 45 and $60 \mathrm{meq} / \mathrm{l})$ on tuberization. Reducing the total nitrogen supply increased number of microtubers but decreased its size. The average weight of microtuber was high with the highest concentration of nitrogen $60 \mathrm{meq} / \mathrm{l}$.

The silicon ( $\mathrm{Si}$ ) is effective on nutrients balance, increased tubers and increased absorption of nitrogen and phosphorus in plants (Khan et al., 1994). After silicon absorption, the element transportation in plants is done through vessel element and transpiration flow from roots to shoots (Ma and Takahashi, 2002). Also, Silicon plays role in growth improvement, photosynthesis increase, efficiency of transpiration and evaporation, increasing the strength of leaves, chlorophyll concentration per leaf area and product quality (Hwang et al., 2005). Best effect of silicon treatment was recorded with $5 \mathrm{mM}$ silicate acid on the growth of potato. The ratio of bound water to free water was increased, the chlorophyll content was enhanced, the respiration rate was decreased significantly, the cell wall extraction rate was increased significantly, the cellulose content was increased by the silicon treatment (Fang and Long 2006). The tomato plants treated with 50 or $100 \mathrm{mg} / \mathrm{l} \mathrm{Si}$ produced heaver weights and larger fruit size (Darshani and Dilshan 2015).

The aim of this work was to investigate the effect of the in vitro application chitosan, calcium chloride and the ratio of ammonium nitrate $\left(\mathrm{NH}_{4} \mathrm{NO}_{3}\right)$ to potassium nitrate $\left(\mathrm{KNO}_{3}\right)$ on potato microtuberization. Besides studying the effect of foliar application of chitosan, chelated calcium and potassium silicate on the production of minituber ex vitro.

\section{MATERIAL AND METHODS}

Two experiments were conducted during the two successive seasons 2012 and 2013 at the Dept. of Potato and Vegetatively Propagated Vegetables, Horticulture research Institute, Dokki, Giza, Egypt. Potato (Solanum tuberosum L.) Diamant cultivar was used. Clean sprouts from tubers were surface sterilized in $10 \% \mathrm{v} / \mathrm{v}$ Clorox solution $(5.75 \%$ of sodium hypochlorite) plus two drops of tween-20, then rinsed three times with sterile distilled water. Shoot tip explants were used as a source of explants. Shoot tip explants established on Murashige and Skoog (1962) (MS) medium $+3 \%$ sucrose $+0.01 \mathrm{mg} / \mathrm{l} \mathrm{NAA}+0.25 \mathrm{mg} / \mathrm{l} \mathrm{GA3}+$ $2.0 \mathrm{mg} / \mathrm{l}$ calcium panthothenic acid after one month the obtained plantlets were used as a 
source of explants for the first experiment (microtuberization). Single node explants (cuttings) were transferred onto jars containing $40 \mathrm{ml}$ of microtuberization media (Table 1) i.e., MS medium $+8 \mathrm{mg} / \mathrm{lBA}+80 \mathrm{~g} / \mathrm{l}$ Sucrose (control) Wang and Hu (1982) (T1), the same medium with chitosan (T2, T3, T4), modified $\mathrm{Cacl}_{2}$ concentrations ( $\mathrm{T} 5, \mathrm{~T} 6, \mathrm{~T} 7$, T8) or modified potassium nitrate $\left(\mathrm{KNO}_{3}\right)$ to ammonium nitrate $\left(\mathrm{NH}_{4} \mathrm{NO}_{3}\right)$ ratio (T9, T10, T11). Each treatment was replicated five times with five jars per replicate. Each jar contained 3 nodal cutting. Jars were distributed randomly in incubation room for month. The statistical design was complete randomize design.

Data on number of shoots/plantlet, node number/plantlet, plantlet height, number of microtubers/ plantlet, shoot fresh weight, shoot dry weight, root fresh weight, microtuber weight/ plantlet, microtuber dry weight were recorded after 8 weeks from culture.

The in vitro produced microtubers were cleaned with tape water, then immersed for 10 minutes in $1 \mathrm{~g} / \mathrm{l}$ Rizolex after that microtubers were dried for one night then in incubated at $25^{\circ} \mathrm{C}$ for 4 weeks to be used in the minituber production experiment.

The second experiment was conducted in the greenhouse using the microtubers produced in the first experiment. Planting dates were September $17^{\text {th }}$ and $22^{\text {th }}$ in 2012 and 2013 seasons, respectively. Microtubers were transferred into pots (40 $\mathrm{cm}$ diameter) filed with mixture of peat moss and sand soil $(2: 1 \mathrm{v} / \mathrm{v})$. Three microtubers were cultured in each pot. Each treatment contained 4 pots per replicate. After full germination the plants were sprayed twice at 45 and 60 days after planting by foliar treatments i.e., Control (water), chitosan, chelated calcium, potassium silicate or mixture of chelated calcium and potassium silicate (Table 2).

The statistical design was complete randomize design with three replicates. The samples were taken at the plant age of 75 days after planting. Data on plant length $(\mathrm{cm})$, leaves number/plant, leaves fresh and dry weight (g.), leaf area $\left(\mathrm{cm}^{2}\right)$, stem fresh and dry weight (g.). Minitubers were harvested after 100 days from planting. At harvest time the minituber characteristics (number of minituber/plant, minituber fresh weight/plant (g), minituber average weight (g), minituber weight of three sizes ( $\leq$ $1.49 \mathrm{~cm}, 1.5-2.99 \mathrm{~cm}$ and $\geq 3 \mathrm{~cm}$ ) and the minituber dry weight/plant $(\mathrm{g})$ were recorded.

Table 1. Additives and modifications to microtuberization media (MS+8 mg/l BA+80 g/l Sucrose).

\begin{tabular}{|c|l|}
\hline Treatments & \multicolumn{1}{|c|}{ Treatments } \\
\hline T1 & Control \\
\hline T2 & $500 \mathrm{mg} / \mathrm{l}$ chitosan \\
\hline T3 & $700 \mathrm{mg} / \mathrm{l}$ chitosan \\
\hline T4 & $900 \mathrm{mg} / \mathrm{l} \mathrm{chitosan}$ \\
\hline T5 & $5 \mathrm{mM} \mathrm{CaCl} \cdot 2 \mathrm{H}_{2} \mathrm{O}$ \\
\hline T6 & $10 \mathrm{mM} \mathrm{CaCl}_{2} \cdot 2 \mathrm{H}_{2} \mathrm{O}$ \\
\hline T7 & $15 \mathrm{mM} \mathrm{CaCl}_{2} \cdot 2 \mathrm{H}_{2} \mathrm{O}$ \\
\hline T8 & $20 \mathrm{mM} \mathrm{CaCl}_{2} \cdot 2 \mathrm{H}_{2} \mathrm{O}$ \\
\hline T9 & $50 \mathrm{mM} \mathrm{KNO}_{3}: 10 \mathrm{mM} \mathrm{NH}_{4} \mathrm{NO}_{3}$ \\
\hline T10 & $55 \mathrm{mM} \mathrm{KNO}_{3}: 5 \mathrm{mM} \mathrm{NH}_{4} \mathrm{NO}_{3}$ \\
\hline T11 & $60 \mathrm{mM} \mathrm{KNO}_{2}: 0 \mathrm{mM} \mathrm{NH}_{4} \mathrm{NO}_{3}$ \\
\hline
\end{tabular}


Nermeen A. E. Abd El Wadod, et al.,

Table (2): Foliar application treatments for enhance minitubers production.

\begin{tabular}{|c|l|}
\hline Treatment & \multicolumn{1}{c|}{ Treatment } \\
\hline T1 & Control ( water) \\
\hline T2 & Chitosan $500 \mathrm{mg} / \mathrm{l}$ \\
\hline T 3 & Chitosan $700 \mathrm{mg} / \mathrm{l}$ \\
\hline T 4 & Chitosan $900 \mathrm{mg} / \mathrm{l}$ \\
\hline T 5 & Chelated Ca $350 \mathrm{mg} / \mathrm{l}$ \\
\hline T 6 & Chelated Ca $500 \mathrm{mg} / \mathrm{l}$ \\
\hline T 7 & K2SiO3 $200 \mathrm{mg} / \mathrm{l}$ \\
\hline T 8 & K2SiO3 $400 \mathrm{mg} / \mathrm{l}$ \\
\hline T 9 & Chelated Ca $350 \mathrm{mg} / \mathrm{l}+\mathrm{K} 2 \mathrm{SiO} 3400 \mathrm{mg} / \mathrm{l}$ \\
\hline
\end{tabular}

The obtained data of both seasons were subjected to the analysis of variance method and the means of the treatments were compared by using the least significant difference (L.S.D) at the level of 0.05 probability according to Snedicor and Cochran (1981).

\section{RESULTS AND DISCUSSIONS First experiment: Microtuberization (in vitro)}

Data in Table 3 showed the tallest plantlets were recorded with the application of $\mathrm{NO}_{3}: \mathrm{NH}_{4}=55: 5 \mathrm{mM}$ followed by the treatments $5 \mathrm{mM} \mathrm{CaCl} 2.2 \mathrm{H}_{2} \mathrm{O}$ and $10 \mathrm{mM}$ $\mathrm{CaCl}_{2} \cdot 2 \mathrm{H}_{2} \mathrm{O}$ without significant difference between the application of $\mathrm{NO}_{3}: \mathrm{NH}_{4}$ $=55: 5 \mathrm{mM}$.

It was clear from results that chitosan at $500 \mathrm{mg} / \mathrm{l}$ gave the highest number of shoots/plantlet (6.4) followed by chitosan at $700 \mathrm{mg} / \mathrm{l} \mathrm{(5.8)}$ and the application of $\mathrm{NO}_{3}: \mathrm{NH}_{4}=55: 5 \mathrm{mM}$ (5.0) compared with control treatment (4.4). Due to calcium chloride concentration, it was obvious that number of shoot/plantlet was significantly decreased with increasing calcium concentrations $(3.2,2.6,2.2$. and 1.6). The nitrogen treatments $\left(\mathrm{NO}_{3}: \mathrm{NH}_{4}=55: 5 \mathrm{mM}\right.$ and $50 \mathrm{mM} \mathrm{KNO}{ }_{3}: 10 \mathrm{mM} \mathrm{NH}_{4} \mathrm{NO}_{3}$ ) followed chitosan treatments were preferable after chitosan treatments for number of node. Moreover, this result was parallel with Avila et al., (1994) who found that potato plantlets growth were less with $\mathrm{NH}_{4}$ or $\mathrm{NO}_{3}$ as a sole source of nitrogen and Villamor (2010) who indicated that nitrogen in the form of $\mathrm{KNO}_{3}$ significantly improved proliferated rate of ginger in vitro. Also, Avila et al., (1994) found that decreasing proportion of $\mathrm{NH}_{4}$ from $50 \%$ to $30 \%$ increased shoot growth. The application of $\mathrm{NO}_{3}: \mathrm{NH}_{4}=55: 5 \mathrm{mM}$ was the best treatment (5.0). There were no significant effect between all the three chitosan treatments and the treatments of nitrogen of $50 \mathrm{mM} \mathrm{KNO}$ : $10 \mathrm{mM} \mathrm{NH}_{4} \mathrm{NO}_{3}$ and $\mathrm{NO}_{3}: \mathrm{NH}_{4}=50: 10$ or $55: 5 \mathrm{mM}$ followed by the control.

Number of microtubers/planlet and microtubers fresh weight took the same trend which were significantly high with chitosan at 500 or $700 \mathrm{mg} / \mathrm{l}$ followed by nitrogen treatments the application of $\mathrm{NO}_{3}: \mathrm{NH}_{4}=55: 5 \mathrm{mM}$ and $50 \mathrm{mM} \mathrm{KNO}$ : 10 $\mathrm{mM} \mathrm{NH} \mathrm{NO}_{3}$. In addition, calcium chloride treatments always produced the lowest number and lightest weight of microtuber. These results parallel with Ozgen and Palta (2004). They found that $\mathrm{Ca}$ application decreased tuber number. These results disagree with Habib et al., (2005) who found that $15 \mathrm{Mm}$ of $\mathrm{Ca}$ application was best for potato plantlets. Moreover, chitosan at 500 $\mathrm{mg} / \mathrm{l}$ produced the heaviest fresh and dry weight followed with significant effect by the application of $50 \mathrm{mM} \mathrm{KNO}_{3}: 10 \mathrm{mM} \mathrm{NH}_{4} \mathrm{NO}_{3}$ or $\mathrm{NO}_{3}: \mathrm{NH}_{4}=55: 5 \mathrm{mM}$. 


\begin{tabular}{|c|c|c|c|c|c|c|c|c|c|c|c|c|}
\hline 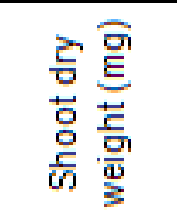 & $\begin{array}{l}\mathbb{2} \\
8\end{array}$ & 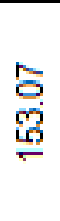 & $\begin{array}{l}\text { ऽ } \\
\text { ㅁ }\end{array}$ & $\begin{array}{l}\text { R } \\
\text { o }\end{array}$ & ले & $\begin{array}{l}8 \\
\text { 心. } \\
\text { 心. }\end{array}$ & $\begin{array}{l}\text { \% } \\
\text { g. }\end{array}$ & 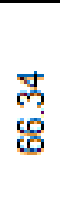 & 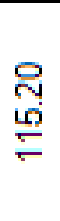 & $\frac{8}{\frac{8}{4}}$ & $\begin{array}{l}\text { ㅇ } \\
\text { 음 }\end{array}$ & 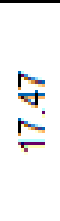 \\
\hline 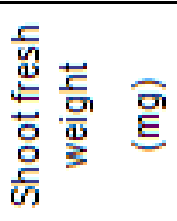 & 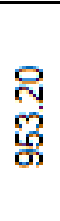 & $\begin{array}{l}\circ \\
\mathscr{8} \\
\stackrel{O}{\square}\end{array}$ & 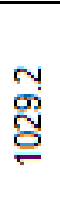 & $\frac{}{ㅇ}$ & $\begin{array}{l}\text { Pे } \\
\text { 寸 }\end{array}$ & 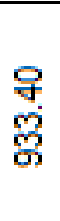 & $\begin{array}{l}\circ \\
\infty \\
\infty \\
\infty\end{array}$ & 옴 & 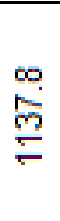 & 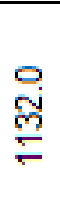 & $\begin{array}{l}\stackrel{ }{0} \\
\text { 守 }\end{array}$ & 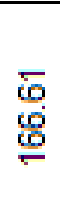 \\
\hline 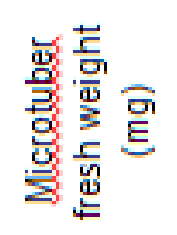 & 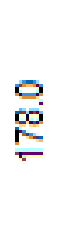 & $\begin{array}{l}\infty \\
\stackrel{\sim}{\sim}\end{array}$ & $\begin{array}{l}\text { 岕 } \\
\text { 岕 }\end{array}$ & ֻั & $\stackrel{\infty}{\stackrel{\infty}{N}}$ & $\begin{array}{l}\text { 옹 } \\
\text { 음 }\end{array}$ & 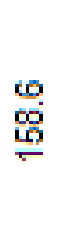 & ঙ্ণু & $\begin{array}{l}\circ \\
\stackrel{+}{\sigma}\end{array}$ & ণ্ণ & 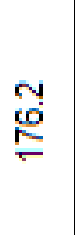 & 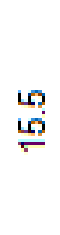 \\
\hline 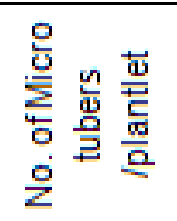 & $\begin{array}{l}\text { ㅇ } \\
\text { 寸 }\end{array}$ & $\underset{r}{8}$ & $\begin{array}{l}\circ \\
\infty \\
\oplus 0\end{array}$ & $\begin{array}{l}8 \\
\stackrel{8}{+}\end{array}$ & 웅 & $\begin{array}{l}\circ \\
\stackrel{\sim}{N}\end{array}$ & 일 & $\stackrel{8}{\circ}$ & $\begin{array}{l}\text { \& } \\
\underset{\forall}{*}\end{array}$ & $\begin{array}{l}8 \\
\text { ํํ }\end{array}$ & ণ্ & $\begin{array}{l}\text { \% } \\
\stackrel{\sigma}{\circ}\end{array}$ \\
\hline 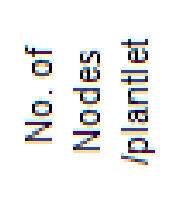 & $\stackrel{\infty}{\sim}$ & $\stackrel{\circ}{\sigma}$ & $\stackrel{\circ}{\circ}$ & $\stackrel{\circ}{\circ}$ & $\underset{0}{\circ}$ & $\stackrel{\infty}{\circ}$ & $\begin{array}{l}\infty \\
\omega\end{array}$ & $\begin{array}{l}\infty \\
\dot{v}\end{array}$ & $\stackrel{\infty}{\sigma}$ & $\stackrel{ }{\dddot{O}}$ & पें & $\stackrel{\text { o }}{\longrightarrow}$ \\
\hline 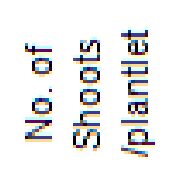 & $\underset{v}{\dot{y}}$ & $\underset{0}{\dot{0}}$ & $\begin{array}{l}\infty \\
\stackrel{\infty}{\infty}\end{array}$ & $\stackrel{\circ}{\stackrel{0}{u}}$ & ભ & $\stackrel{\circ}{\sim}$ & $\underset{N}{N}$ & $\stackrel{\infty}{\circ}$ & $\stackrel{\circ}{\forall}$ & 웅 & $\stackrel{\infty}{\sim}$ & $\stackrel{m}{\longrightarrow}$ \\
\hline 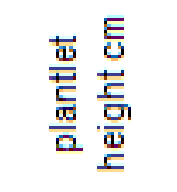 & さे & $\begin{array}{l}\infty \\
\infty \\
\infty \\
\infty\end{array}$ & $\underset{N}{N}$ & ro & ભొ & $\stackrel{+}{E}$ & $=$ & 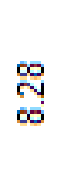 & $=$ & $\stackrel{\mathscr{O}}{\stackrel{\leftrightarrow}{\leftarrow}}$ & $\begin{array}{l}\text { ్ } \\
\text { 으 }\end{array}$ & $\stackrel{\infty}{-}$ \\
\hline 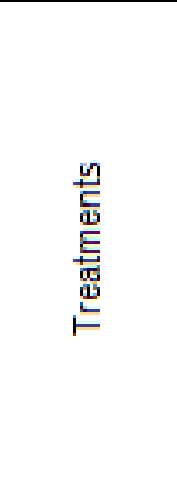 & $\begin{array}{l}\overline{0} \\
\text { 등 } \\
\text { 인 }\end{array}$ & 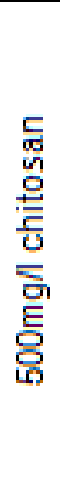 & 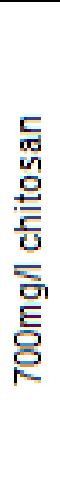 & 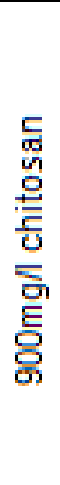 & 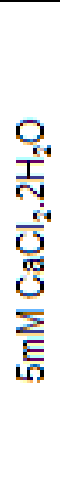 & 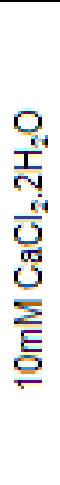 & 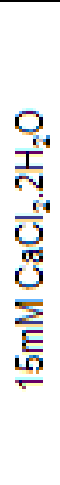 & 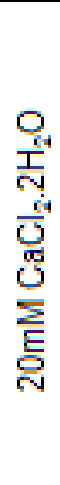 & 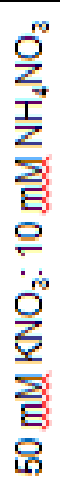 & 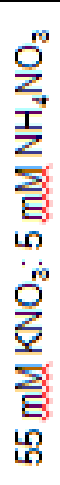 & 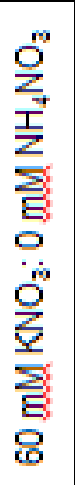 & $\begin{array}{l}\text { 웅 } \\
\text { ○ं } \\
\text { on }\end{array}$ \\
\hline
\end{tabular}


Finally, chitosan at $500 \mathrm{mg} / \mathrm{l}$ showed the best results of number of shoot, node, microtuber/planlets, microtuber fresh weight $(\mathrm{mg})$, and shoot fresh or dry weight. This results matched with Zakaria et al., (2009) who reported that $500 \mathrm{mg} / \mathrm{l}$ significantly increased shoot number followed by nitrogen treatments at $\mathrm{NO}_{3}: \mathrm{NH}_{4}=50: 10$ or $55: 5 \mathrm{mM}$, respectively. increasing calcium concentration caused dramatic decline in characteristic.

\section{Second experiment: Minituber production experiment). (greenhouse}

Data in Table (4) indicate that, severe changes in plant growth, manifested by vegetative parameters were recorded at 75 days after planting as affected by the foliar application of chitosan, chelated calcium, calcium silicate and the mixture between chelated calcium and potassium silicate. In this respect, all the presented results of plant growth characters significantly increased due to the application of the experiment treatments. The largest increase in plant length was observed with the application $400 \mathrm{mg} / \mathrm{l}$ of potassium silicate followed by the mixture of $350 \mathrm{mg} / \mathrm{l}$ chelated calcium $+400 \mathrm{mg} / \mathrm{l}$ potassium silicate or $200 \mathrm{mg} / \mathrm{l}$ the potassium silicate without significant differences between the three treatments. These results agree with Hwang et al., (2005) who declared that Silicon plays very important role in growth improvement, photosynthesis increase, efficiency of transpiration and evaporation, increasing the strength of leaves, chlorophyll concentration per leaf area and product quality. While, there was a clear reduction in the plant length with the foliar application of chitosan as a result of the decrease of internodal distance as mentioned by Zakaria et al., (2009)

The highest significant values of leaves number arranged in descending with the 500 $\mathrm{mg} / \mathrm{l}$ chitosan, mixture of $350 \mathrm{mg} / \mathrm{l}$ chelated calcium $+400 \mathrm{mg} / \mathrm{l}$ potassium silicate and
$500 \mathrm{mg} / \mathrm{l}$. chelated calcium. The results also cleared that the leaves fresh and dry weight have the same trend, with concern that the heaviest significant values recoded with the $500 \mathrm{mg} / \mathrm{l}$ chitosan and the mixture of chelated calcium $350 \mathrm{mg} / \mathrm{l}+400 \mathrm{mg} / \mathrm{l}$ potassium silicates. Otherwise, the highest leaf area per plant were obtained with the mixture of $350 \mathrm{mg} / \mathrm{l}$ chelated calcium +400 $\mathrm{mg} / \mathrm{l}$ potassium silicates followed by the first and second chitosan levels respectively. These findings agree with Zakaria et al., (2009) who cleared that the chitosan level of $500 \mathrm{mg} / \mathrm{l}$ increased either the leaves or stems fresh and dry weight.

Data referred to the response of stems fresh and dry weight to the foliar application of the chitosan, chelated calcium, potassium silicate and the mixture of chelated calcium + potassium silicate at the plant age of 75 days after planting. The highest value of stem fresh weight was recorded with the 500 $\mathrm{mg} / \mathrm{l}$ chitosan. These results agree with Zakaria et al., (2009) who found that the application of chitosan at $500 \mathrm{mg} / \mathrm{l}$ significantly increased the stems fresh and dry weight. On the other side, the stem dry weight was recorded with the mixture of chelated calcium $350 \mathrm{mg} / \mathrm{l}+400 \mathrm{mg} / \mathrm{l}$ potassium silicates followed with $350 \mathrm{mg} / \mathrm{l}$ chelated calcium or $400 \mathrm{mg} / \mathrm{l}$ potassium silicate. Such results confirm those of Salim et al., 2014 who mentioned that the higher rate of potassium silicate had a significant effect on stems fresh and dry weight on the open field.

Data in Table (5) showed that the minituber characteristics at the harvest time after 100 days from planting were significantly affected by the foliar spray of chitosan, chelated calcium, calcium silicate and the mixture between chelated calcium and potassium silicate. The acquired data indicated that the $500 \mathrm{mg} / \mathrm{l}$ chitosan or the mixture of $350 \mathrm{mg} / \mathrm{l}$ chelated calcium +400 $\mathrm{mg} / \mathrm{l}$ potassium silicates gave the highest significant minituber number. While the control, $900 \mathrm{mg} / \mathrm{l}$ chitosan and $200 \mathrm{mg} / \mathrm{l}$ 


\begin{tabular}{|c|c|c|c|c|c|c|c|c|c|c|}
\hline 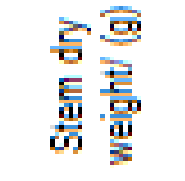 & $\mathbf{8}$ & 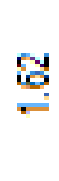 & 9 & $\frac{10}{2}$ & 18 & 8 & 9 & tᄒ & 8 & 8 \\
\hline 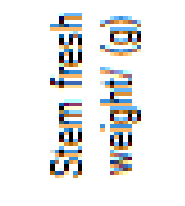 & $\begin{array}{l}\text { 호 } \\
\text { แn }\end{array}$ & $\frac{9}{6}$ & is & $\begin{array}{l}9 \\
\end{array}$ & 通 & $\begin{array}{l}\text { Z } \\
\mathbb{S}\end{array}$ & $\frac{5}{m}$ & $\begin{array}{l}8 \\
\text { ष }\end{array}$ & $\begin{array}{l}9 \\
:\end{array}$ & $\begin{array}{l}8 \\
6 \\
5\end{array}$ \\
\hline 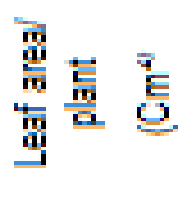 & $\begin{array}{l}89 \\
9\end{array}$ & 部 & $\begin{array}{l}8 \\
\text { 辛 }\end{array}$ & N & 感 & 8 & 5 & 8 & $\begin{array}{l}8 \\
8 \\
8\end{array}$ & $\begin{array}{l}8 \\
8\end{array}$ \\
\hline 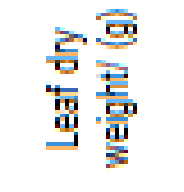 & 8 & $\frac{19}{61}$ & 8 & 8 & 8 & $\frac{9}{3}$ & $\Rightarrow$ & $\frac{7}{4}$ & $\frac{48}{5}$ & $\frac{8}{8}$ \\
\hline 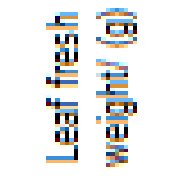 & 8 & $\mathrm{~m}$ & $\frac{8}{8}$ & 8 & $\frac{4}{4}$ & $\frac{9}{4}$ & $\begin{array}{l}8 \\
8\end{array}$ & 茪 & $\begin{array}{l}\mathbf{5} \\
\mathbf{5}\end{array}$ & 8 \\
\hline 夏畐畐 & 8 & $\begin{array}{l}\frac{9}{4} \\
\end{array}$ & $\frac{8}{8}$ & $\begin{array}{l}49 \\
\text { S }\end{array}$ & $\begin{array}{l}\text { 零 } \\
53\end{array}$ & $\frac{m}{5}$ & 8 & $\begin{array}{l}4 \\
8 \\
5\end{array}$ & $\begin{array}{l}\text { 울 } \\
\pm\end{array}$ & 9 \\
\hline 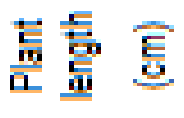 & 8 & $\mathrm{~m}$ & 8 & 8 & $\mathrm{~s}$ & 8 & $\begin{array}{l}8 \\
\dot{0}\end{array}$ & $\begin{array}{l}5 \\
58\end{array}$ & $\begin{array}{l}5 \\
\frac{5}{4}\end{array}$ & 8 \\
\hline 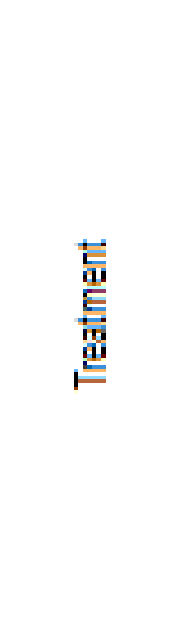 & 을 & 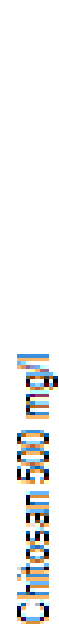 & 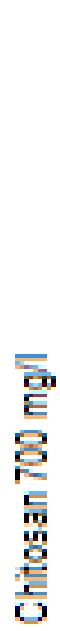 & 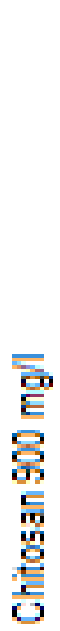 & 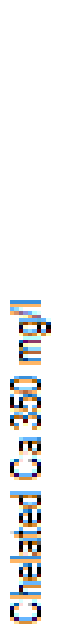 & 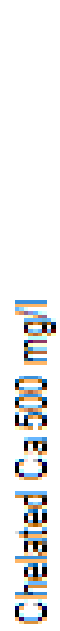 & $\begin{array}{l}\overline{5} \\
\text { 吾 } \\
8 \\
8 \\
8 \\
8\end{array}$ & $\begin{array}{l}\overline{\overline{0}} \\
\bar{E} \\
8 \\
8 \\
8 \\
8\end{array}$ & 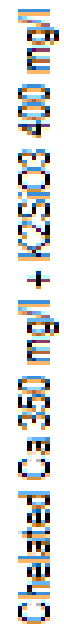 & $\begin{array}{l}8 \\
8 \\
0 \\
0 \\
\end{array}$ \\
\hline
\end{tabular}


Nermeen A. E. Abd El Wadod, et al.,

\begin{tabular}{|c|c|c|c|c|c|c|c|c|c|c|c|}
\hline \multicolumn{2}{|c|}{ 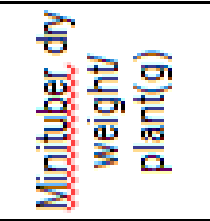 } & 巳 & $\underset{\sim}{\stackrel{D}{N}}$ & $\stackrel{\text { \% }}{\circ}$ & $\stackrel{\infty}{\dddot{r}}$ & f & $\stackrel{\infty}{-}$ & 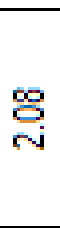 & $\stackrel{\text { \% }}{\longrightarrow}$ & $\begin{array}{l}\text { 昂 } \\
\text { in }\end{array}$ & $\stackrel{\text { ֻొ }}{\circ}$ \\
\hline \multirow{3}{*}{ 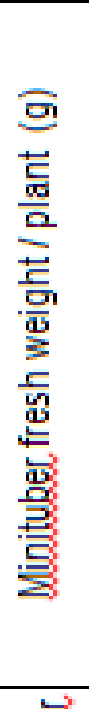 } & $\begin{array}{l}\text { 틍 } \\
\text { M } \\
\text { 怠 } \\
\text { N }\end{array}$ & $\stackrel{\sigma}{\sim}$ & $\begin{array}{l}\text { f } \\
\text { 它 }\end{array}$ & mis & 용 & $\underset{m}{E}$ & 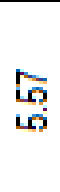 & 导 & 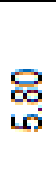 & స్ & $\stackrel{\infty}{\infty}$ \\
\hline & 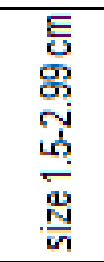 & $\underset{\text { ल }}{=}$ & Or & $\underset{m}{F}$ & $\underset{m}{m}$ & $\begin{array}{l}8 \\
\text { ஸீ }\end{array}$ & $\underset{\sim}{\mathscr{\sim}}$ & ৪్లా & $\underset{\omega}{F}$ & $\stackrel{F}{N}$ & $\stackrel{\overbrace{}}{\rightleftarrows}$ \\
\hline & 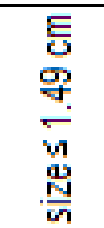 & mo & స్ & 요 & ס & 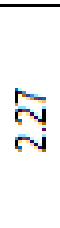 & f & 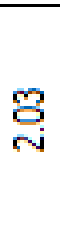 & $\begin{array}{l}\text { gु } \\
\text { 寸 }\end{array}$ & 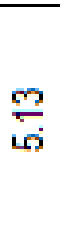 & 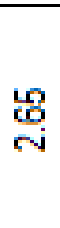 \\
\hline \multicolumn{2}{|c|}{ 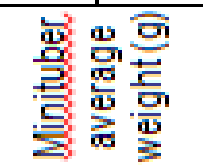 } & लn & $\underset{\substack{0 \\
\forall}}{ }$ & 을 & స్లి & 只 & $\underset{m}{\stackrel{m}{m}}$ & 呙 & $\underset{\forall}{8}$ & $\underset{\forall}{\text { g }}$ & 志 \\
\hline \multicolumn{2}{|c|}{ 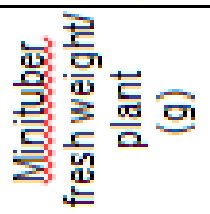 } & $\begin{array}{l}\text { 융 } \\
\text { 은 }\end{array}$ & $\begin{array}{l}\kappa \\
\text { D }\end{array}$ & پి & :0 & 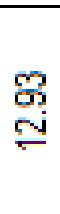 & 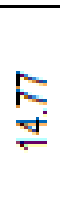 & लై & $\begin{array}{l}8 \\
0\end{array}$ & $\stackrel{\sigma}{\sigma}$ & \begin{tabular}{l}
$\mathscr{8}$ \\
\hdashline \\
\hdashline
\end{tabular} \\
\hline \multicolumn{2}{|c|}{ 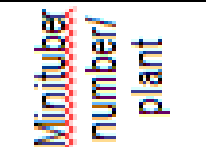 } & 이 & $\begin{array}{l}\text { ơ } \\
\forall\end{array}$ & $\underset{\forall}{8}$ & m & ద్ & $\underset{\forall}{8}$ & ֻِ & $\underset{\forall}{8}$ & $\begin{array}{l}\mathscr{6} \\
\dot{q}\end{array}$ & $\stackrel{8}{\circ}$ \\
\hline \multicolumn{2}{|c|}{ 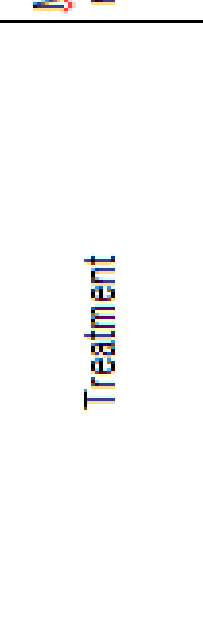 } & $\begin{array}{l}\text { 은 } \\
\text { 등 }\end{array}$ & 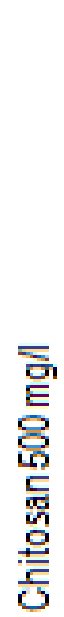 & 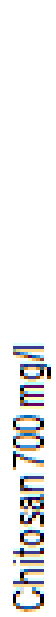 & 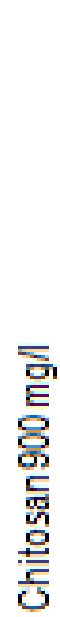 & 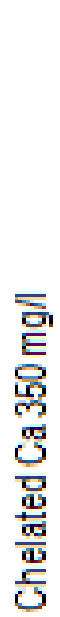 & 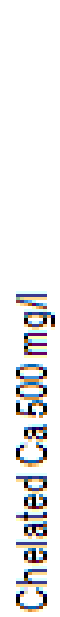 & 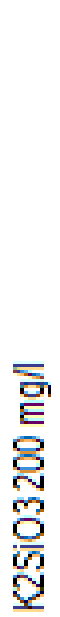 & 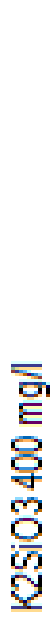 & 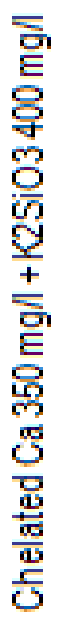 & 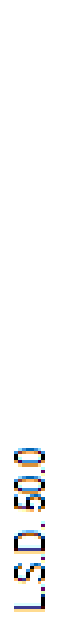 \\
\hline
\end{tabular}


potassium silicate gave the lowest significant minituber number. Moreover, the heaviest minituber fresh weight was mentioned with the $500 \mathrm{mg} / \mathrm{l}$ chitosan with concern that there were no significant differences between this level of chitosan and the mixture of $350 \mathrm{mg} / \mathrm{l}$ chelated calcium +400 $\mathrm{mg} / \mathrm{l}$ potassium silicates or $400 \mathrm{mg} / \mathrm{l}$ potassium silicate . Furthermore, the highest minituber weight was obtained from the foliar application of chitosan $500 \mathrm{mg} / \mathrm{l}$ and the mixture of $350 \mathrm{mg} / \mathrm{l}$ chelated calcium +400 $\mathrm{mg} / \mathrm{l}$ potassium silicates but this result has no significant differences with 500 mg/l chelated calcium or $400 \mathrm{mg} / \mathrm{l}$ potassium silicate.

The recorded data cleared that the highest values of small minitubers ( $\leq 1.49$ $\mathrm{cm}$ ) were obtained in control followed by 500 $\mathrm{mg} / \mathrm{l}$ chitosan or the mixture of $350 \mathrm{mg} / \mathrm{l}$ chelated calcium $+400 \mathrm{mg} / \mathrm{l}$ potassium silicates. In contrary, the lowest significant weight was found with $350 \mathrm{mg} / \mathrm{l}$ chelated calcium or $200 \mathrm{mg} / \mathrm{l}$ potassium silicate.

Data in Table (5) cleared that the highest significant weights of medium size minituber $(1.5-2.99 \mathrm{~cm})$ were arranged in descending order as the mixture of $350 \mathrm{mg} / \mathrm{l}$ chelated calcium $+400 \mathrm{mg} / \mathrm{l}$ potassium silicates, 500 $\mathrm{mg} / \mathrm{l}$ chitosan, $350 \mathrm{mg} / \mathrm{l}$ chelated calcium or $400 \mathrm{mg} / \mathrm{l}$ potassium silicate. Regarding the results in the same table, data clearly showed that $500 \mathrm{mg} / \mathrm{l}$ chitosan and the mixture of $350 \mathrm{mg} / \mathrm{l}$ chelated calcium +400 $\mathrm{mg} / \mathrm{l}$ potassium silicates recorded the highest significant values of the weight of tuber size equal or more than $3 \mathrm{~cm}$. Also, the data showed that the mixture of $350 \mathrm{mg} / \mathrm{l}$ chelated calcium $+400 \mathrm{mg} / \mathrm{l}$ potassium silicate gave the heaviest significant minituber dry weight with concern that there were no significant differences between this treatment and $500 \mathrm{mg} / \mathrm{l}$ of chitosan. The results on minituber yield and its components agree with those obtained with Arvin et al., (2005) who mentioned that the minituber number and weight were increased with the application of calcium.
These results agree also with Zakaria et al., (2009) who stated that $500 \mathrm{mg} / \mathrm{l}$ chitosan significantly increased the minituber yield. Also, Salim et al., (2014) found that foliar application of potassium silicate significantly increased the tubers number/plant and the tubers weight/plant.

\section{Conclusion:}

The treatment of chitosan enhanced the microtuber growth characters followed by $\mathrm{NO}_{3} / \mathrm{NH}_{4}$ ratio 50: 10 or 55: $5 \mathrm{mM}$. Also 500 $\mathrm{mg} / \mathrm{l}$ chitosan or the mixture of $350 \mathrm{mg} / \mathrm{l}$ chelated calcium $+400 \mathrm{mg} / \mathrm{l}$ potassium silicate enhanced the minituber production and yield characteristics.

\section{REFERENCES}

Andreea, N., C. Nicoleta and B. Carmen (2011). Effect of inorganic nitrogen on in vitro production of potato microtubers. Proceeding of the $4^{\text {th }}$ International Symposium. New research in biotechnology "USAMV" Bucharest, Romania. 51-55.

Arvin, M. J., A. Habib and D. J. Donnely (2005). Effect of calcium concentrations in medium on microtuberization of potato (Solanum tuberosum L.) . Iranian J. Biotech. Vol. 3, No. 3., 152-156.

Avila, A. L., S. M. Pereyra, D. J. Collino and J. A. Arguello (1994). Effects of nitrogen source on growth morphogenesis of three micropropagated potato cultivars. Potato Res. 37: 161-168.

Balamani, V., K. Veluyhambi and B. W. Poovaiah (1986). Effect of calcium on tuberization in potato. Plant Physiol. 80 : 856-858.

Darshani W. and D. Dilshan (2015). Effect of silicon and potassium on tomato anthracnose and on the postharvest quality of tomato fruit (Lycopersicon esculentum Mill.). J. Natn. Sci. Foundation Sri Lanka (3):273-280.

Donnelly, D. J., W. K. Coleman, and S. E. Coleman (2003). Potato microtuber and performance; A review. Am. J. potato Res. 80: 103-115. 
Fang J. Y. and M. X. Long (2006). Effect of silicon on the growth of test- tube potato plantlets and the cell wall formation. Acta Agronomica Sinica.. 32 (1) : 152-154.

George, E. F, M. A. Hall and G. Dekerk (2008). Plant propagation by tissue culture $3^{\text {rd }}$ edition Vol. 1. The background. published by springer 2008.pp 305.

Habib, A., J. Abdulnour and D. J. Donnelly (2005). Increased calcium availability improves potato micropropagation and microtuberization. Potato Res. 47 :139 150.

Hwang, S.J., H. M. Park and B. R. Jeong (2005). Effect of potassium silicate on the growth of miniature rose 'Pinocchio' grown on rock wool and its cut flower quality. Journal of the Japanese Society for Horticultural Science. 74: 242-247.

Kawakami, J., K. Iwama, T. Hasegawa and Y. Jitsuyama (2003). Growth and yield potato plants grown from microtubers in fields. Amer J. of Potato Res. 80:371378.

Khan, H.R., S. Elahi, M. S. Hussain and T. Adachi (1994). Soil characteristics and behavior of potassium under various moisture regimes. Soil Science and Plant Nutrition. 40(2): 234-254.

Kowalski, B., F. J. Terry, L. Herrera and D. A. Penalver (2006). Application of soluble chitosan in vitro and in the greenhouse to increase yield and seed quality of potato minitubers. Potato Res., 49: 167-176.

Ma, J.F. and E. Takahashi (2002). Soil, Fertilizer and Plant Silicon Research in Japan. Elsevier Science, Amsterdam, The Netherlands. P 294.
Motallebi-Azar, A., S. Kazemiani, F. Kiumarsie and N. Mohades (2011). Shoot proliferation from node explants of potato (Solanum tuberosum L.) cv. Agria. II. Effect of different concentrations of $\mathrm{NH}_{4}$ $\mathrm{NO}_{3}$ hydrolyzed casein and BAP. Romanian Biotechnology Letters 16 (3): 6181-6186.

Murashige, T. and F. Skoog (1962). A revised medium for rapid growth and bio assays with tobacco tissue cultures. Plant Physiology, 15: 473-497.

Ozgen, S. and J. P. Palta (2004). Supplement al calcium application influences potato tuber number and size. HortScience. 40: 102-105.

Salim, B. B. M., H. G. Abd El-Gawad and A. Abou El-Yazied, (2014). Effect of Foliar Spray of Different Potassium Sources on Growth, Yield and Mineral Composition of Potato (Solanum tuberosum L.). Middle East Journal of Applied Sciences, 4(4): 1197-1204.

Snedecor, D. M. and W. G. Cochran (1981). Statistical Methods. 7th Ed., lowa state Univ. press., Ames, USA, p.305.

Villamor, C. C. (2010). Influence of media strength and sources of nitrogen on micropropagation of ginger, Zingiber officiale rosc. E-International scientific Res. Jour. 2: 1749-2094.

Zakaria, R. A., B. M. Zanjani and E. Sedghi (2009). Effect of in vitro chitosan application on growth and minituber yield of Solanum tuberosum L. Plant Soil Environ., 55, (6) : 252-256.

Wang, p. j. and C. Y. Hu (1982). Effect of medium composition on In vitro tuberization. Am. Potato J. 64: 462. 
تحسين انتاج و مواصفات الميكروتيوير والميني تيوير في البطاطس

نرمين عبد التواب المنادي عبد الودود و احمد محمد حامد عبد العال و نادية محمد ابراهيم معهد بحوث البساتين - مركز البحوث الزراعية - مصر

الملخص العربي

اجريت هذه الدراسة خلال موسمي النمو 2012 و 2013 علي البطاطس صنف دايمونت بمعمل زراعة

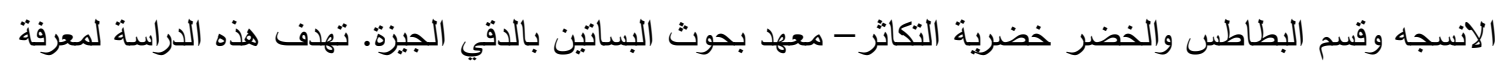

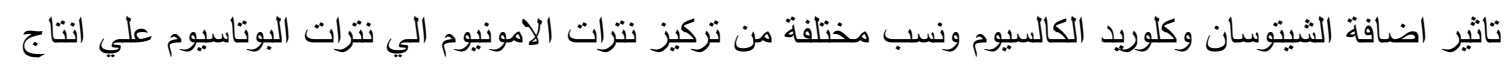

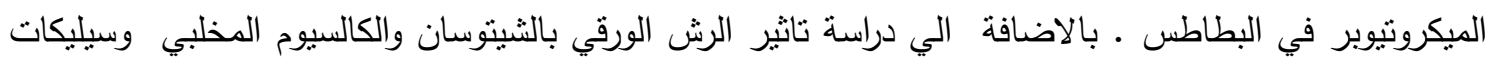

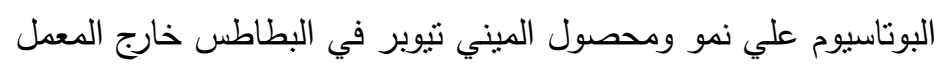

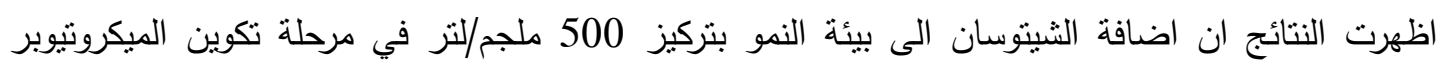

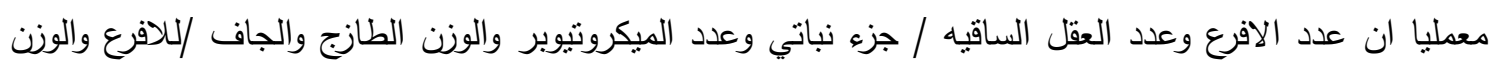

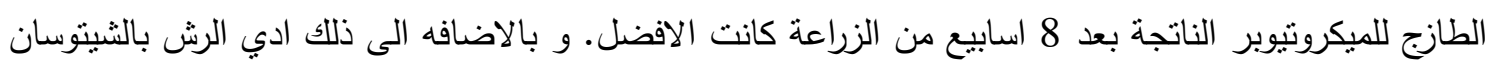

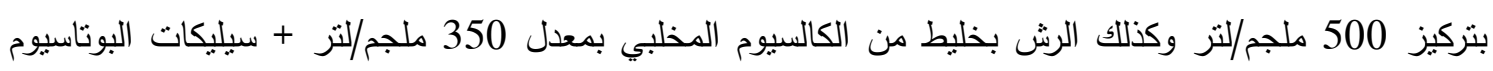

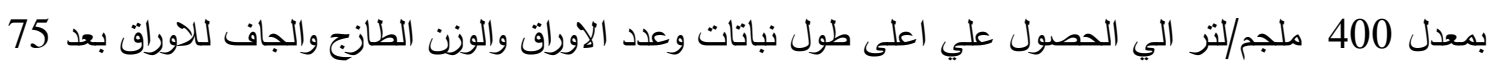

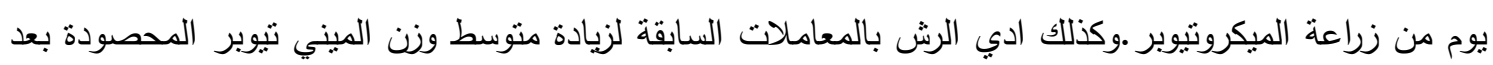
100 يوم من الزراعه. وتوصي الدراسة باستخدام الثيتوسان بتركيز 500 ملجم/لتر داخل المعل لانتاج افضل صفات نمورومحصصول

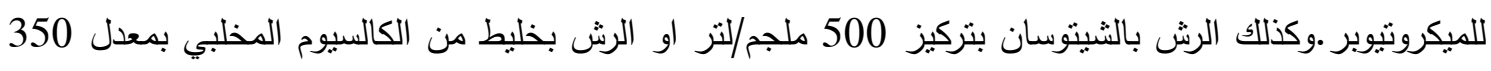

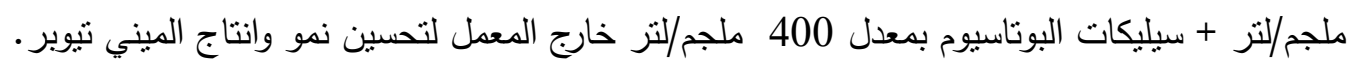

